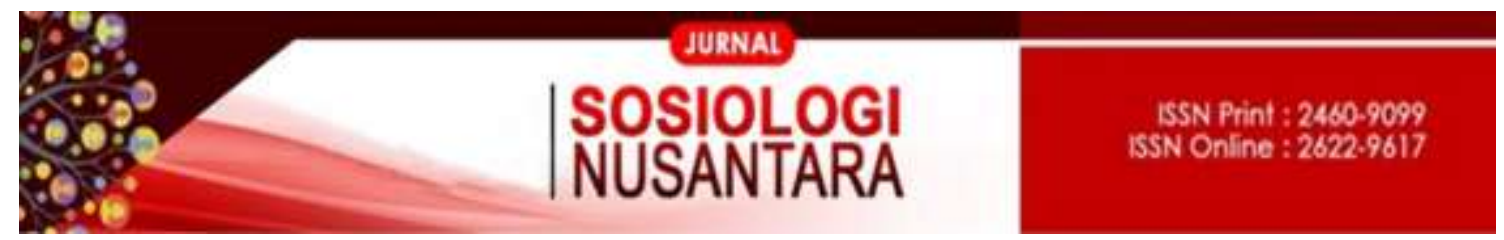

https://ejournal.unib.ac.id/index.php/jsn

DOI ://doi.org/10.33369/jsn.5.2.126-139

\title{
PERAN PEER GROUP DALAM MEMBENTUK PERILAKU KONSUMTIF MAHASISWA FAKULTAS EKONOMI, UNIVERSITAS SRIWIJAYA
}

\section{THE ROLE OF PEER GROUP IN FORMING CONSUMPTIVE BEHAVIOR OF ECONOMIC FACULTY, SRIWIJAYA UNIVERSITY}

\author{
Jhulia Destisya ${ }^{1}$, Ria Septika², Yoyok Hendarso ${ }^{3}$, Yusnaini ${ }^{4}$ \\ jhuliadestisya@gmail.com \\ 1234 Fakultas Ilmu Sosial dan Ilmu Politik, Universitas Sriwijaya
}

\begin{abstract}
Abstrak
Penelitian ini bertujuan untuk memahami peran peergroup dalam membentuk perilaku konsumtif mahasiswa Fakultas Ekonomi Universitas Sriwijaya, dan untuk memahami perilaku konsumtif pada mahasiswa Fakultas Ekonomi Universitas Sriwijaya, Palembang. Metode yang digunakan dalam penelitian ini adalah deksriptif kualitatif. Teknik pengumpulan data yang digunakan dalam penelitian ini adalah observasi, wawancara mendalam dan dokumentasi. Teori yang digunakan untuk menganalisis pemasalahan penelitian ini adalah teori cermin diri dari Charles Horton Cooley, yang menjelaskan bahwa seseorang bertindak berdasarkan penilaian atau persepsi orang lain. Dari penelitian ini diketahui bahwa latar belakang terbentuknya peer group yakni adanya perkembangan proses sosialisasi, kebutuhan untuk menerima penghargaan dari lingkungannya, dan kesamaan hobi. Peran yang ada di dalam peer group mahasiswa Fakultas Ekonomi Universitas Sriwijaya sebagai konformitas, yaitu meniru tindakan teman di dalam kelompoknya. Perilaku konsumtif yang dilakukan oleh mahasiswa yakni dengan menggunakan barang-barang bermerek untuk dapat menunjang status dan gaya hidup mereka. Perilaku konsumtifnya ditunjukkan dengan beberapa hal berikut : a) membeli barang bermerek hanya untuk kesenangan; b) membeli barang bermerek untuk bersaing dalam hal penampilan; c) penggunaan barang bermerek untuk menunjang rasa percaya diri; d) membeli barang-barang bermerek di luar kebutuhan (boros).
\end{abstract}

Kata Kunci : Peer Group Mahasiswa, Perilaku Konsumtif, Teori Cermin Diri

\section{Abstract}

The objectives of this study were to find out the role of peer group in encouraging consumption behavior in students of Economy Faculty of Palembang campus of Sriwijaya University as well as to find out consumption behavior in the students. The research method used in this study is qualitative descriptive research. Technique of data collection was done by employing observations, interviews, and documentation. In this study, theory used to analyze the research questions was looking-glass self created by 
Charles Horton Cooley, who stated that, a person's self grows out of society's interpersonal interactions and the perceptions of others. The result of the study showed that the formation the peer group was triggered by the development of socialization process, the needs of receiving awards from surroundings, and the shared hobby. The role found in the peer group of students of Economy Faculty of Palembang campus of Sriwijaya University was perceived as conformity, which is imitating other members of the group. Consumption behavior was committed by the students by buying branded goods to either attain or maintain the given social status and their life style. The consumption behavior was shown by the following attitudes namely; a) buying branded good for pleasure, b) buying branded goods for appearance rivalry, c) using branded goods for attaining confidence, d) buying branded goods out of necessity (extravagant behavior).

Keywords: Peer Group Of Students, Consumerist Behaviour, Theory Of Self Mirror

\section{PENDAHULUAN}

Pada saat ini masyarakat telah mengenal gaya hidup yang menganggap bahwa materi sebagai sesuatu yang dapat mendatangkan suatu kepuasan, hal itu dapat terlihat dari cara mereka menggunakan barang-barang atau pun pakaian yang bermerek. Dan tidak menutup kemungkinan barang-barang tersebut kebanyakan didapat dari belanja di mall dengan harga yang mahal dibandingkan dengan barang-barang yang dijual di luar mall seperti di pasar-pasar tradisional. Adanya perubahan pemenuhan kebutuhan dalam masyarakat, di mana masyarakat tidak hanya memenuhi kebutuhan primernya saja berupa sandang, pangan, dan papan, tetapi mereka juga memenuhi kebutuhan sekunder dan tersiernya berupa kebutuhan akan barang-barang, dan pakaian bermerek.

Faktanya berdasarkan data survey yang dirilis pada tahun 2015 oleh Lembaga Perlindungan Konsumen. Menunjukkan adanya permintaan barang-barang mewah yang cukup signifikan. Berdasarkan data yang sebelumnya hanya 3,8 \% bertambah menjadi $21 \%$ dari total permintaan barang selama tahun 2015. Berdasarkan survey yang telah dilakukan dan dimuat di kompas, menunjukkan bahwa permintaan akan barang-barang mewah yang berupa tas, pakaian, sepatu dan aksesoris dengan brand mahal dan terpopuler yang cukup signifikan tersebut terjadi pada kalangan menengah atas maupun kalangan menegah ke bawah (yang memiliki penghasilan sekitar Rp 900.000 Rp9.000.000 per bulan) hal ini menunjukkan adanya kecenderungan masyarakat kelas menengah menjadi konsumtif. 
Konsumtif biasanya menjelaskan keinginan untuk memiliki atau mengkonsumsi barang secara berlebihan yang sebenarnya kurang diperlukan atau bukan menjadi kebutuhan pokok, sehingga konsumtif cenderung mengarah pada perilaku boros yang lebih mendahulukan keinginan daripada kebutuhan. Konsumtif biasa digunakan untuk menunjuk pada perilaku konsumen yang memanfaatkan nilai uang lebih besar dari nilai produksinya, untuk barang dan jasa yang bukan menjadi kebutuhan pokok (Tambunan, 2001: 1). Perilaku konsumtif pada umumnya berada di lingkungan yang berstatus sosial ekonomi tinggi namun saat ini orang dari kalangan menengah ataupun dari kalangan ekonomi kelas bawah pun sudah mengikuti perilaku konsumtif tersebut, dan perilaku tersebut pun tidak hanya dilakukan oleh orang yang sudah memiliki penghasilan sendiri tetapi juga dilakukan oleh remaja yang belum mempunyai pendapatan sendiri.

Faktor lingkungan sosial yakni kelompok teman sebaya (peer group) memberikan peranan yang sangat besar terhadap pembentukan perilaku konsumtif pada mahasiswa, karena kelompok teman sebaya merupakan hubungan persahabatan antar remaja, di mana kelompok teman sebaya (peer group) biasanya memiliki usia yang lebih kurang sama, serta terikat dengan kepentingan yang sama (Henslin, 2007: 75). Pada umumnya peer group terikat atas dasar ketertarikan dan aktivitas bersama yang bersifat timbal balik dan memiliki sifat-sifat antara lain adanya saling pengertian dan saling membantu, saling percaya, saling menghargai serta saling menerima. Menurut Monks dalam (Tresna, 2013: 17), biasanya individu cenderung mengikuti pola hidup konsumtif dari kelompok teman sebayanya (peer group). Oleh karena itu, apabila salah satu teman membeli produk atau barang tertentu remaja yang lain cenderung akan ikutikutan membeli.

Berdasarkan fenomena yang telah dikemukakan diatas maka peneliti tertarik untuk meneliti tentang "Peran Peer Group Dalam Membentuk Perilaku Konsumtif Mahasiswa Fakultas Ekonomi Universitas Sriwijaya”. Kelompok peer group (teman sebaya) pada mahasiswa dipilih sebagai fokus kajian karena keberadaan mereka yang secara ekonomis belum produktif dalam menggunakan barang-barang sesuai kebutuhan, namun kini individu cenderung memiliki perilaku untuk tampil dengan mengikuti trend dan mode yang ada di lingkungan pergaulan mereka.

Penelitian ini memilih lokasi Fakultas Ekonomi Universitas Sriwijaya karena merupakan salah satu perguruan tinggi yang mahasiswanya tidak terlepas dari gaya 
hidup metropolitan, dimana mahasiswa Fakultas Ekonomi Universitas Sriwijaya cenderung menggunakan pakaian dan barang-barang yang lebih mengikuti mode, baik di dalam maupun di luar kampus untuk menunjukkan status serta menunjang gaya hidup mereka, hal ini berbeda dengan mahasiswa yang kuliah di kampus Indralaya yang cenderung menggunakan pakaian yang lebih sederhana. Terdorong oleh kenyataan tersebut maka penelitian ini perlu dilakukan untuk mendapatkan pemahaman tentang Peran Peer Group Dalam Membentuk Perilaku Konsumtif Mahasiswa Fakultas Ekonomi Kampus Palembang Universitas Sriwijaya. Berdasarkan uraian yang telah dipaparkan dalam latar belakang permasalahan di atas, maka yang menjadi pertanyaan permasalahan dalam penelitian adalah: 1). Bagaimana peran peer group dalam membentuk perilaku konsumtif mahasiswa Fakultas Ekonomi Universitas Sriwijaya? serta 2). Bagaimana perilaku konsumtif pada mahasiswa Fakultas Ekonomi Universitas Sriwijaya, Palembang?

\section{METODE PENELITIAN}

Penelitian ini merupakan penelitian kualitatif yang bersifat deskriptif dengan pendekatan observasi partisipan, menggunakan unit analisis kelompok yaitu anggota peer group Fakultas Ekonomi Universitas Sriwijaya. Penentuan informan dilakukan secara purposive dengan 12 informan. Teknik analisis data dilakukan dengan tiga tahap yaitu tahap domain yaitu proses analisis data secara keseluruhan melibatkan usaha memaknai data yang berupa teks atau gambar.

\section{PEMBAHASAN}

1. Peran Peer Group dalam Membentuk Perilaku Konsumtif Mahasiswa Fakultas Ekonomi Kampus Palembang Universitas Sriwijaya

\subsection{Latar Belakang Terbentuknya Peer Group pada Mahasiswa Fakultas Ekonomi Kampus Palembang Universitas Sriwijaya}

Dalam kehidupan sebagai makhluk sosial, manusia terus berusaha mengembangkan dirinya untuk dapat diterima oleh kelompoknya. Perkembangan diri manusia dijelaskan oleh Cooley dalam teorinya looking glass self, dimana Cooley melihat bahwa konsep diri seseorang berkembang melalui interaksinya dengan orang lain. Usaha mencari identitas untuk menjelaskan siapa dirinya dan peran dalam 
masyarakat menyebabkan remaja banyak berada di luar rumah bersama peer group (kelompok teman sebaya) menjadi suatu sarana sekaligus tujuan dalam pencarian jati diri mereka. Menurut Santosa (2004: 77), ada beberapa aspek yang menimbulkan peer group diantaranya sebagai berikut:

\section{a. Adanya Perkembangan Proses Sosialisasi}

Dalam kelompok teman sebaya (Peer group) akan memungkinkan individu untuk saling berinteraksi, bergaul dan memberikan semangat dan motivasi terhadap teman sebayanya secara emosional. Adanya ikatan secara emosional dalam kehidupan peer group akan mendatangkan berbagai manfaat dan pengaruh yang besar bagi individu yang berada dalam kelompok tersebut, termasuk dalam hal perilaku konsumtif terhadap barang-barang bermerek yang dapat menunjukkan status dan menunjang gaya hidupnya. Sehingga dengan demikian dapat disimpulkan bahwa peer group adalah sekelompok teman sebaya yang mempunyai ikatan emosional yang kuat dan mereka dapat berinteraksi, bergaul, bertukar pikiran dan pengalaman dalam memberikan pembentukan sikap dalam kehidupan sosial dan pribadinya.

Proses sosialisasi yang terdapat pada peer group mahasiswa, berawal dari situasi di mana mereka mengawali kuliah pertamanya. Karena adanya interaksi yang terjadi pada mahasiswa ketika mereka bertemu di kampus, menyebabkan mereka lebih sering menghabiskan waktu bersama, mulai dari kegiatan belajar di dalam kelas, ketika istirahat di kantin kampus, dan lain sebagainya. Interaksi yang terus terjalin melalui kebersamaan dengan teman-temannya tersebut yang menyebabkan terbentuknya suatu pertemanan yang akrab seperti peer group (kelompok teman sebaya), yang secara tidak langsung dapat membentuk suatu perilaku yang bisa dikatakan sebagai perilaku konsumtif, hal ini dapat terlihat dari kebiasaan mereka yang banyak menghabiskan waktu di tempat-tempat yang terbilang dapat menunjukkan status dan gaya hidupnya dengan nongkrong bersama teman-temannya di cafe, dan beberapa restoran cepat saji (fast food).

\section{b. Kebutuhan Untuk Menerima Penghargaan Dari Lingkungannya}

Secara psikologis, individu butuh penghargaan dari orang lain, agar mendapat kepuasan dari apa yang telah dicapainya. Penghargaan dalam hal ini yaitu berupa pujian dari orang-orang yang ada lingkungan terdekatnya, yakni keinginan untuk dapat diterima dan dihargai oleh teman-teman sebayanya. Oleh karena itu individu bergabung 
dengan teman sebayanya yang mempunyai kebutuhan psikologis yang sama, yaitu ingin dihargai. Sehingga individu merasakan kebersamaan atau kekompakan dalam kelompok teman sebayanya. Dalam hal ini untuk dapat dihargai dan diterima oleh teman sebaya (peer group) di lingkungan kampusnya, hal ini ditunjukkan oleh informan yang berperilaku konsumtif, dengan menggunakan barang-barang atau mengkonsumsi barang-barang yang dapat menunjukkan status dan menunjang gaya hidupnya. Kebutuhan akan perhatian dari orang lain, menjadikan seseorang bisa melakukan dan mengupayakan suatu cara untuk bisa mendapat suatu perhatian dari orang-orang sekitarnya. Perhatian dalam hal ini dapat berupa respon positif dari lingkungan terdekatnya yakni berupa pujian.

\section{c. Kesamaan Hobi}

Didalam peer group, individu dapat menemukan dunianya, dimana berbeda dengan dunia orang dewasa. Mereka mempunyai persamaan pembicaraan disegala bidang. Misalnya : pembicaraan tentang hobi dan hal-hal menarik lainnya. Kesamaan dalam bidang hobi dapat menjadikan orang-orang yang awalnya tidak akrab, akhirnya menjadi semakin akrab dengan kesamaan hobi yang mereka miliki. Dengan kesamaan hobi ini juga, menyebabkan terbentuknya peer group.

\subsection{Konformitas}

Sarwono (2008: 220) mendefinisikan konformitas adalah kesesuaian antara perilaku individu dengan perilaku kelompoknya atau perilaku individu dengan harapan orang lain tentang perilakunya. Konformitas didasari oleh kesamaan antara perilaku dengan perilaku atau antara perilaku dengan norma.

Berdasarkan pengertian diatas diketahui bahwa konformitas itu sendiri merupakan suatu perubahan sikap, perilaku atau kepercayaan seorang individu agar sesuai dengan norma kelompok atau norma sosial sebagai akibat tekanan kelompok yang nyata atau dibayangkan. Dalam hal ini, yang ditiru oleh beberapa orang yang terdapat didalam peer group mahasiswa, yaitu teman yang mereka anggap memiliki penampilan yang modis. Hal ini dilakukan agar dapat diterima dalam kelompok acuannya. 


\section{a. Meniru Tindakan Teman Kelompoknya}

Berdasarkan pengamatan yang telah di lakukan dalam penelitian ini, bahwa terdapat peer group (kelompok teman sebaya) mahasiswa yang sangat memperhatikan penampilan mereka, baik di dalam maupun di luar kampus. Hal ini terlihat dari barangbarang bermerek yang mereka gunakan seperti tas, sepatu, dan lain sebagainya. Gaya penampilan (fashion) dikalangan mahasiswa memiliki banyak faktor yang mempengaruhi, salah satunya adalah peniruan. Hal ini merupakan cerminan bahwa setiap orang bisa menjadi siapa saja sesuai dengan apa dan siapa yang ditirunya, termasuk teman sebayanya.

Dalam hal ini mahasiswa di dalam peer group sebenarnya sudah berperilaku konsumtif, hal ini ditunjukkan dengan kebiasaan mereka yang suka berbelanja bersama keluarganya dalam memenuhi keinginannya terhadap barang-barang tertentu seperti tas, sepatu, dan kosmetik. Selain itu, karena mereka memiliki teman-teman yang juga berperilaku konsumtif membuat mereka menjadi semakin konsumtif. Hal ini ditunjukkan ketika salah satu anggota dari peer group membeli kosmetik yaitu lipstik Make Over, salah satu toko di mall Palembang Icon. Maka teman-temanya yang ada di dalam peer group juga akan membeli lipstik yang sama dengan teman yang menjadi acuan mereka didalam kelompoknya. Mahasiswa sebagai remaja yang masih dalam tahap pekembangan akan lebih mudah untuk dipengaruhi oleh lingkungan sekitarnya, seperti kelompok teman sebaya (peer group) yang dijadikan sebagai acuan mereka dalam melakukan berbagai tindakan yang konsumtif. Hal ini dikarenakan mahasiswa masih dalam proses pencarian jati diri, di mana lingkungan dapat membentuk jati dirinya termasuk perilaku konsumtif.

Hal ini serupa dengan apa yang disampaikan oleh Cooley dalam teorinya mengenai looking glass self (teori cermin diri), dimana ia mengatakan bahwa suatu refleksi diri bahwa suatu tindakan dilakukan atas dasar apa yang ada di dalam cermin atau dengan kata lain seseorang bertindak berdasarkan penilaian atau persepsi orang lain terhadap kita. Sama halnya dengan asumsi teori dari Cooley tersebut, mahasiswa yang menjadi informan dalam penelitian ini melakukan suatu tindakan untuk meniru orang lain sebagai acuannya, hal ini mereka lakukan agar mereka terlihat keren dalam hal berpenampilan, serta agar mereka dapat menunjukkan status sosialnya melalui fashion. 
133 I Jhulia Destisya, Ria Septika, Yoyok Hendarso, Yusnaini

Peran Peer Group Dalam Membentuk Perilaku Konsumtif .....

\section{Perilaku Konsumtif Mahasiswa Fakultas Ekonomi Universitas Sriwijaya}

Di dalam teori looking glass self (teori cermin diri) terdapat tiga konsep penting, dimana dalam individu senantiasa terjadi suatu proses yang ditandai dengan 3 tahap terpisah yaitu sebagai berikut :

\subsection{Membeli Barang Bermerek Hanya Untuk Kesenangan (Pleasure Seeking)}

Perilaku konsumsi berdasarkan untuk mencari kesenangan, telah menyebabkan perilaku konsumsi yang tidak sesuai dengan kebutuhan. Bentuk perilaku konsumsif yang tidak sesuai dengan kebutuhan di sini dikarenakan barang-barang yang dikonsumsi oleh mahasiswa yang ada di Fakultas Ekonomi Universitas Sriwijaya tersebut sebenarnya tidak diperlukan. Kepuasan terhadap suatu barang tertentu dapat diketahui dari pengalaman mereka sendiri saat menggunakan produk tersebut, omongan-omongan orang lain, dan lain sebagainya.

Perilaku konsumtif pada mahasiswa tersebut dapat dilihat dari segi penampilan mereka. Mahasiswa yang konsumtif selalu berpenampilan dengan menggunakan barang-barang yang sesuai dengan selera mereka dan bisa menunjang gaya hidup mereka, mengenakan fashion bermerk, dan mengikuti perkembangan trend. Dari segi penampilan, cara berpakaian mahasiswa tersebut selalu terkesan menarik.

Maka dapat disimpulkan bahwa selera seseorang dalam membeli dan menggunakan suatu barang tergantung dengan seperti apa penilaian dari orang-orang yang berada di sekitar mereka, termasuk teman sebayanya (peer group). Hal ini sangat penting dan menentukkan penampilan seorang mahasiswa, apakah itu penilaian baik berupa penerimaan oleh teman-temannya atau malah penilaian buruk berupa olok-an dari temannya. Apabila memiliki selera yang cukup bagus maka secara tidak langsung akan mendapatkan suatu penghargaan dari teman-teman sebayanya sebagai orang yang fashionable (modis). Selera yang bagus akan membuat seseorang mudah diterima di lingkungannya. Ketika para informan tersebut menggunakan barang sesuai dengan selera yang diinginkannya agar dapat diterima dilingkungannya, para informan tersebut telah memiliki rasa kepuasan tersendiri terhadap barang yang sesuai dengan selera mereka tersebut.

\subsection{Membeli Barang Bermerek Untuk Bersaing Dalam Hal Penampilan}

Bagian dari perilaku konsumtif salah satunya adalah kontrol diri dari setiap individu. Lemahnya pengendalian diri membuat seseorang mudah tergiur terhadap suatu 
objek. Perilaku yang konsumtif tidak hanya memberikan dampak pada ekonomi, namun berdampak pada kehidupan sosial yang akhirnya kecemburuan sosial. Sikap inilah yang mendorong setiap kalangan, tanpa memandang status ekonomi di dalam masyarakat bersaing untuk menunjukkan status dan menunjang gaya hidup mereka, dengan memakai suatu barang atau produk tertentu secara berlebihan. Persaingan pribadi merupakan suatu persaingan antar masing-masing orang secara langsung bersaing. Persaingan individu sendiri tidak hanya dilakukan oleh individu yang tidak memiliki kelompok tapi secara keseluruhan baik yang masuk dalam suatu kelompok maupun yang tidak. Bahkan, dalam kelompok pun ada persaingan-persaingan saling gengsi satu sama lain dalam hal apa pun terutama mengenai penampilan.

Perilaku konsumtif mahasiswa saat ini tercermin dari cara mereka berpakaian dan berpenampilan atau fashion baik di dalam atau di luar kampus, selain itu juga dapat diketahui dari banyaknya koleksi yang mereka miliki terhadap suatu jenis barang atau produk tertentu, baik itu berupa koleksi tas, berbagai kosmetik, sepatu, tas, aksesoris, atau intensitas mereka mengunjungi cafe untuk sekedar nongkrong atau berkumpul bersama teman-temannya. Kecenderungan mahasiswa yang mengikuti trend sehingga berdampak terhadap status sosial mereka di kampus. Berdasarkan fenomena tersebut dapat memicu terjadinya kompetisi atau persaingan di kalangan mahasiswa yang ingin menunjukkan status sosialnya melalui fashion.

Mahasiswa yang konsumtif menghabiskan waktu luang mereka untuk nongkrong di cafe bersama teman-temannya, dan kadang mereka belanja walaupun tidak memiliki rencana untuk belanja sebelumnya sebagai penghilang rasa jenuh, sebagai kepuasan tersendiri dan lebih banyak bergaul dengan orang-orang yang memiliki hobi yang sama dalam banyak hal dengan mereka. Persaingan ini tentu mengarah pada siapa yang memiliki kemampuan untuk dapat menunjukkan status sosialnya dengan lebih dulu memiliki barang-barang tertentu. Hal inilah yang kemudian melatarbelakangi perilaku konsumsif yang tidak berdasarkan pada kebutuhan.

\subsection{Penggunaan Barang Bermerek Untuk Menunjang Rasa Percaya Diri}

Self Confidence atau kepercayaan diri adalah sikap positif seorang individu yang memampukan dirinya untuk mengembangkan penilaian positif terhadap diri sendiri dan terhadap lingkungan atau situasi yang dihadapinya. Menurut (Santrock, 2007: 205) kebiasaan mengkonsumsi barang-barang bermerek yang dilakukan oleh informan 
menjadikan mereka merasa percaya diri untuk dapat berinteraksi dengan lingkungan terdekatnya, yaitu teman-temannya di lingkungan kampus. Dengan adanya rasa percaya diri yang mereka miliki membuat mereka dengan mudah bergaul dengan temantemannya dan dihargai oleh teman-temannya.

Merasa percaya diri dengan apa yang mereka pakai dalam hal penampilan yaitu barang-barang bermerek yang mereka pakai. Selain itu dengan adanya teman-temannya yang modis juga menambah rasa percaya dirinya dalam hal berpenampilan. Ia mengatakan karena teman-temannya modis, maka setiap apa yang mereka gunakan akan dipuji oleh teman-temannya tersebut hal ini dikarenakan baginya pujian dari temantemannya merupakan suatu penghargaan dan pengakuan bahwa mereka juga merupakan orang yang modis juga sama seperti teman-temannya. Dalam hal ini rasa percaya diri yang dimiliki informan didasarkan atas barang bermerek yang mereka pakai, serta karena adanya teman-temannya yang modis juga menambah rasa percaya dirinya dalam hal berpenampilan.

\subsection{Membeli Barang Bermerek Diluar Kebutuhan (Boros)}

Konsumsi yang dilakukan secara berlebihan atau boros biasanya dilakukan karena banyak pilihan barang yang akan dikonsumsi. Barang-barang yang dipilih pun tidak hanya barang-barang yang dibutuhkan tetapi juga barang-barang yang diinginkan. Sehingga tanpa disadari pengeluaran pun sangat besar. Dalam hal ini Cooley mengatakan bahwa respon yang ditunjukkan yaitu, dimana setiap tindakan yang dilakukan oleh informan berdasarkan tanggapannya terhadap penilaian orang lain kepadanya. Mereka meniru tindakan teman-temannya agar tidak berbeda atau tidak ketinggalan dari teman-teman sebayanya dalam mengkonsumsi sejumlah barang tertentu. Inilah yang menyebabkan mereka mengkonsumsi secara berlebihan, agar apa yang ingin mereka wujudkan yakni mengkonsumsi barang-barang bermerek dapat terwujud walaupun mereka bahkan rela saling meminjam uang kepada teman-temannya.

Perilaku konsumtif yang boros disebabkan oleh konsumsi yang tidak sesuai dengan kemampuan daya beli. Dimana untuk dapat diterima oleh lingkungan di sekitarnya, agar tidak dinilai berbeda dari teman-temannya, dan untuk mendapat suatu penghargaan dari teman-temannya, maka beberapa informan di atas mewujudkan keinginannya untuk membeli dan memiliki berbagai barang bermerek yang mereka nilai dapat menunjang status dan gaya hidupnya dengan meminta uang lebih di luar uang 
sakunya kepada orang tuanya. Serta meminjam uang kepada temannya untuk membeli dan memiliki barang-barang bermerek yang ingin dibelinya namun uang yang dimilikinya pada saat itu tidak mencukupi.

\section{KESIMPULAN}

Dari hasil yang telah dijelaskan pada bab sebelumnya maka dapat penulis kemukakan beberapa kesimpulan, sekaligus sebagai jawaban dari rumusan masalah yang sudah ditetapkan sebelumnya: Adanya peer group mahasiswa di Fakultas Ekonomi Kampus Palembang Universitas Sriwijaya, dikarenakan adanya aspek-aspek yang menjadi latar belakang terbentuknya peer group tersebut yakni berupa adanya perkembangan proses sosialisasi, kebutuhan untuk menerima penghargaan dari lingkungannya, dan kesamaan hobi. Dalam hal perilaku konsumtif yang dilakukan mahasiswa Fakultas Ekonomi Universitas Sriwijaya bersama peer group-nya, ternyata peer group mempunyai peranan yang sangat penting. Peran yang dilakukan di dalam peer group mahasiswa Fakultas Ekonomi Universitas Sriwijaya tersebut yaitu sebagai konformitas. Konformitas adalah kesesuaian antara perilaku individu dengan perilaku kelompoknya atau perilaku individu dengan harapan orang lain tentang perilakunya. Dimana konformitasnya, yakni meniru tindakan teman di dalam kelompoknya. Para informan berperilaku meniru dengan orang-orang yang menjadi acuannya dalam hal berpenampilan dan dalam mengkonsumsi barang tertentu. Dalam hal ini beberapa mahasiswa mengkonsumsi barang-barang bermerek berdasarkan penampilan orang lain, seperti teman-teman di lingkungan kampus dengan latar belakang ekonomi menengah ke atas. Para informan mengonsumsi berlebihan terhadap barang-barang bermerek, karena adanya keinginan untuk sama seperti teman-temannya membuat mereka terus mengkonsumsi barang-barang atau produk yang mereka anggap bisa menunjang status dan gaya hidupnya.

Perilaku konsumtif yang dilakukan oleh mahasiswa Fakultas Ekonomi Universitas Sriwijaya, dilakukan agar barang-barang bermerek yang mereka gunakan dapat menunjang status dan gaya hidup mereka. Perilaku konsumtif yang ditunjukkan oleh mahasiswa Fakultas Ekonomi Universitas Sriwijaya bersama peergroup-nya yaitu a). Membeli barang bermerek hanya untuk kesenangan, yaitu selera seseorang dalam membeli dan menggunakan suatu barang tergantung dengan seperti apa penilaian dari 
orang-orang yang berada di sekitar mereka, termasuk teman sebayanya (peer group). Selera yang bagus akan membuat seseorang mudah diterima dilingkungannya; $b$ ) Membeli barang bermerek untuk bersaing dalam hal penampilan, yakni persaingan ini tentu mengarah pada siapa yang memiliki kemampuan untuk dapat menunjukkan status sosialnya dengan lebih dulu memiliki barang-barang tertentu. Hal inilah yang kemudian melatarbelakangi perilaku konsumsif yang tidak berdasarkan pada kebutuhan; c) Penggunaan barang bermerek untuk menunjang rasa percaya diri, yakni dalam hal ini rasa percaya diri yang dimiliki informan didasarkan atas barang bermerek yang mereka pakai, serta karena adanya teman-temannya yang modis juga menambah rasa percaya dirinya dalam hal berpenampilan; d) Membeli barang-barang bermerek di luar kebutuhan (boros), yakni bahwa perilaku konsumtif yang dilakukan oleh informan hanya berdasarkan pada apa yang ditampilkan kepada orang lain, melalui gaya hidup serta barang-barang yang digunakan. Kebutuhan yang dipenuhi bukan merupakan kebutuhan yang utama, tetapi kebutuhan yang hanya mengikuti lingkungan disekitarnya dan ingin memperoleh identitas dari lingkungannya terdekatnya; hal ini menyebabkan perasaan tidak puas pada individu ketika barang-barang yang diinginkan belum dimiliki, yakni dalam hal ini keinginan informan akan suatu barang tertentu yang belum bisa ia miliki membuatnya tidak tenang dan menambah beban pikirannya untuk terus memikirkan barang atau produk tersebut, dan akhirnya membuatnya tetap membeli barang yang memang menjadi keinginannya tersebut, walaupun barang tersebut bukan kebutuhan yang mendesak untuk dipenuhi melainkan suatu barang yang sebenarnya kurang diperlukan.

\section{DAFTAR PUSTAKA}

Bagong, Suyanto. 2013. Sosiologi Ekonomi Kapitalisme dan Konsumsi di Era Masyarakat Post-Modenisme.

Baron, Robert A., Byrne, Donn. 2005. Psikologi Sosial Edisi 10. Jakarta: Erlangga

Bugin, Burhan. 2010. Analisis Data Penelitian Kualitatif. Jakarta: Raja GrafindoPersada.

Bugin, Burhan. 2012. Analisis Data Penelitian Kualitatif. Jakarta: Raja GrafindoPersada. 
Creswell, John W. 2012. Research Design; Pendekatan Kualitatif, Kuantitatif dan Mixed. Yogyakarta: Pustaka Pelajar.

Damsar. 1997.Sosiologi Ekonomi. Jakarta: Rajawali Press.

Damsar. 2002. Sosiologi Ekonomi. Jakarta: Raja Grafindo Persada.

Forum HEDS. 2007. Bidang Ilmu Sosiologi. Jakarta: Forum HEDS.

Gerungan, W A. 2010. Psikologi Sosial. Bandung: Refika Aditama.

Henslin, James M. 2007. Sosiologi Dengan Pendekatan Membumi. Jakarta: Raja Grafindo Persada.

Hurlock, Elisabeth B. 2001. Psikologi Perkembangan. Jakarta: Erlangga.

Lury, Celia. 2001. Budaya Konsumen. Jakarta: Yayasan Obor Indonesia.

Mappiare, A. 1982.Psikologi Remaja. Surabaya: Usaha Nasional.

Moleong, Lexy J. 2005. Metodologi Penelitian Kualitatif. Bandung: Remaja Rosda Karya.

Purnama, Dadang H. 2004. Modul Ajar Metode Penelitian Kualitatif. Palembang: Jurusan Sosiologi Universitas Sriwijaya.

Ritzer, George. 2012. Teori Sosiologi Dari Sosiologi Klasik Sampai Perkembangan Terakhir Postmodern. Edisi Kedelapan. Yogyakarta: Pustaka Pelajar.

Soekanto, Soerjono. 2002. Sosiologi Suatu Pengantar. Jakarta: Raja Grafindo Persada.

Soekanto, Soerjono. 2009. Sosiologi Suatu Pengantar. Jakarta: Raja Grafindo Persada.

Sugiyono. 2011. Metode Penelitian Pendidikan Pendekatan Kuantitatif, Kualitatif. Dan $R \& D$. Bandung: Alfabeta.

Sugiyono.2013. Metode Penelitian Pendidikan Pendekatan Kuantitatif, Kualiitatif. Dan $R \& D$. Bandung: Alfabeta.

Tambunan, R. 2001. Remaja dan Perilaku Konsumtif. Jakarta: Raja Grafindo. 
139 I Jhulia Destisya, Ria Septika, Yoyok Hendarso, Yusnaini

Peran Peer Group Dalam Membentuk Perilaku Konsumtif .....

Usman, Husainidan Akbar, S. Purnomo. 2008. Metodologi Penelitian Sosial. Jakarta:BumiAksara.

Sofianita, Sania dan Harti. 2013. Pengaruh Teman Sebaya (Peer Group) Terhadap Imitation Behavior Pembelian Aksesoris pada Remaja (Studi Pada Siswi SMA Negeri 11 Surabaya.Jurnal. Surabaya: Universitas Negeri Surabaya. (Diakses pada tanggal 5 Mei 2016).

Tresna, Trigita Ardikawati Java. 2013.Perilaku Konsumtif Di Kalangan Mahasiswa FIS UNY Pada Klinik Kecantikan".Jurnal. Yogyakarta: Universitas Negeri Yogyakarta. (Diakses pada tanggal 5 Mei 2016).

Wahyudi. 2013. Tinjauan Tentang Perilaku Konsumtif Remaja Pengunjung Mall Central Plaza Samarinda. Jurnal Sosiologi. Samarinda: Universitas Mulawarman. (Diakses pada tanggal 5 Mei 2016).

www.kompasiana.com Diakses pada tanggal 9 April 2017

Zaldiansyah, M. 2005. Hubungan antara Beberapa Karakteristik Kelompok Teman Sebaya denga Motivasi Belajar Siswa Kelas dua SMA Karya Sejati.Jurnal. Palembang: STIPSI Widya Dharma. (Diakses pada tanggal 5 Mei 2016). 